\title{
Studies on electron transfer reactions of Keggin-type mixed addenda heteropolytungstovanadophosphates with NADH
}

\author{
PONNUSAMY SAMI and KASI RAJASEKARAN* \\ Post Graduate Department of Chemistry, Virudhunagar Hindu Nadars' Senthikumara Nadar College, \\ Virudhunagar 626001 \\ e-mail: krsekaran $@$ yahoo.com
}

MS received 15 November 2008; revised 8 December 2008

\begin{abstract}
The coenzyme nicotinamide adenine dinucleotide (NADH) undergoes facile electron transfer reaction with vanadium $(\mathrm{V})$ substituted Keggin-type heteropolyanions (HPA) $\left[\mathrm{PV}^{\mathrm{V}} \mathrm{W}_{11} \mathrm{O}_{40}\right]^{4-}\left(\mathrm{PV}_{1}\right)$ and $\left[\mathrm{PV}_{2}{ }_{2} \mathrm{~W}_{10} \mathrm{O}_{40}\right]^{5-}\left(\mathrm{PV}_{2}\right)$ in aqueous phosphate buffer of $\mathrm{pH} 6$ at ambient temperature. Electrochemical and optical studies show that the stoichiometry of the reaction is $1: 2$ (NADH : HPA). EPR and optical studies show that HPA act as one electron acceptor and the products of electron transfer reactions are one electron reduced heteropoly blues (HPB), viz. $\left[\mathrm{PV}^{\mathrm{IV}} \mathrm{W}_{11} \mathrm{O}_{40}\right]^{5-}$ and $\left[\mathrm{PV}^{\mathrm{IV}} \mathrm{V}^{\mathrm{V}} \mathrm{W}_{10} \mathrm{O}_{40}\right]^{6-}$. Oxygraph measurements show that there is no uptake of molecular oxygen during the course of reaction. The reaction proceeds through multi-step electron-proton-electron transfer mechanism, with rate limiting initial one electron transfer from NADH to HPA by outer sphere electron transfer process. Bimolecular rate constant for electron transfer reaction between $\mathrm{NADH}$ and $\mathrm{PV}_{2}$ in phosphate buffer of $\mathrm{pH}=6$ has been determined spectrophotometrically.
\end{abstract}

Keywords. Nicotinamide adenine dinucleotide (NADH); heteropoly-tungstovanadophosphate; outer sphere electron transfer reactions.

\section{Introduction}

Nicotinamide adenine dinucleotide (NADH) is a coenzyme found in all living cells. It is easily oxidized to $\mathrm{NAD}^{+}$by the enzymes present in biological system.

$$
\mathrm{NADH} \rightleftharpoons \mathrm{NAD}^{+}+\mathrm{H}^{+}+2 \mathrm{e} \text {. }
$$

The redox couple NADH/NAD ${ }^{+}$plays an important role in biological reactions involving electron transfer. ${ }^{1-3}$ Studies on the electron transfer reaction of NADH and its synthetic analogue were reported by several workers. ${ }^{4-10}$ The mechanism of reaction of NADH largely depends on the nature of oxidants. When the oxidants are iminium ions of activated carbonyl compounds ${ }^{11}$ and quinone, ${ }^{12}$ there is a transfer of hydride ion from the 4th position of the dihydropyridine ring to the oxidizing agent in the rate limiting step (scheme 1).

Oxidation of NADH by ferrocenium ${ }^{3}$ and ferrricyanide $^{11}$ proceeds through multi-step electronproton-electron transfer mechanism in which the

*For correspondence initial electron transfer from NADH to the oxidant is the rate limiting step.

Vanadium plays an important role in a number of biological process. ${ }^{13-16}$ The metal vanadium exists in several oxidation states viz. $+1,+2,+3,+4$ and +5 . Vanadium in +5 oxidation state can act as one electron or two electron acceptor in electron transfer reactions. In the Keggin-type heteropolytungstophosphate, $\mathrm{W}^{\mathrm{VI}}$ can be replaced by $\mathrm{V}^{\mathrm{V}}$ without affecting structure of the HPA. ${ }^{17,18}$ Vanadium substituted HPA are ideal candidates for the study of electron transfer reactions. ${ }^{19-21}$ By changing the composition, the redox potential of HPA can be varied to span a wide range. They can formally act as one electron, two electron or even several electron acceptors. Therefore, it was thought of interest to<smiles>[R]N1C=CCC(C(N)=[18O])=C1</smiles>

Scheme 1. 
study the electron transfer reactions of NADH with vanadium substituted HPA. The present investigation may give valuable information on the biologically important reactions involving NADH.

\section{Experimental}

Disodium salt of NADH (Boehringer Manheim $\mathrm{GmbH}$ ) was used as such. Potassium salt of vanadium $(\mathrm{V})$ substituted heteropolytungstovanadophosphates, viz. $\mathrm{K}_{4}\left[\mathrm{PV}^{\mathrm{V}} \mathrm{W}_{11} \mathrm{O}_{40}\right] \cdot 2 \mathrm{H}_{2} \mathrm{O}$ and $\mathrm{K}_{5}\left[\mathrm{PV}_{2}{ }^{\mathrm{V}}\right.$ $\left.\mathrm{W}_{10} \mathrm{O}_{40}\right] \cdot 3 \mathrm{H}_{2} \mathrm{O}$ were prepared and characterized by the method described by Domaille. ${ }^{22}$ The $\mathrm{pH}$ of the solution was maintained with $\mathrm{KH}_{2} \mathrm{PO}_{4}$ buffer. ${ }^{23}$ All the $\mathrm{pH}$ measurements were made with Philips $\mathrm{pH}$ meter.

Electrochemical studies were carried out using EG\&G Princeton Applied Research Potentiostat/ Galvanostat Model 273 A, controlled by M-270 software. Cyclic voltammetric measurements were performed using three electrode assembly of glassy carbon electrode (working), platinum electrode (auxiliary) and $\mathrm{Ag} / \mathrm{AgCl}$ electrode (reference). Glassy carbon electrode was resurfaced with alumina. The solution was taken in the cell, purged with nitrogen for $5 \mathrm{~min}$. and the cyclic votammograms (CV) were recorded.

Oxygen consumption studies were carried out using an oxygraph; Model 18172 fitted with Clark electrode (Yellow Springs Co., Yellow Springs, $\mathrm{OH})$. First the electrode was calibrated to $100 \%$ air saturation using a solution containing HPA $(0.2 \mathrm{mM})$ in phosphate buffer with constant stirring to obtain a steady base line. Then NADH $(0 \cdot 1 \mathrm{mM})$ was added and oxygen consumption was measured for about 8 min.

Shimadzu Model UV-1601 UV-Visible spectrophotometer was used to record the optical spectra. EPR spectra were recorded on a Varian E-109 Xband spectrometer at room temperature. The following parameters were set for the measurements: microwave power, $20 \mathrm{~mW}$; modulation amplitude, $0.05 \mathrm{mT}$; modulation frequency, $100 \mathrm{kHz}$. For the EPR measurements, a reaction mixture containing $\mathrm{PV}_{1} / \mathrm{PV}_{2}(0.2 \mathrm{mM})$ and NADH $(0.1 \mathrm{mM})$ in buffer solution $(\mathrm{pH}=6)$ was prepared. The sample solutions after the completion of the reaction were drawn into aqueous flat cell and then placed in the EPR cavity.

The kinetics of oxidation of NADH by $\mathrm{PV}_{2}$ was investigated under second order condition with equal and unequal concentration of the reactants
(NADH and $\mathrm{PV}_{2}$ ). The progress of the reaction was monitored by following the decrease in the absorbance at $340 \mathrm{~nm}$. Typical concentrations of NADH were 0.10 to $0.20 \mathrm{mM}$ while that of $\mathrm{PV}_{2}$ were 0.15 to $0.20 \mathrm{mM}$. The reaction was initiated by adding required volume of NADH into the $\mathrm{PV}_{2}$ in aqueous $\mathrm{pH} 6.0$ phosphate buffer. The quartz cuvette containing the reaction mixture was thermostated to $30 \cdot 0 \pm 0 \cdot 2^{\circ} \mathrm{C}$ in the cell holder of a Hitachi Model 200-20 UV-Visible spectrophotometer. Time vs absorbance readings were then recorded and bimolecular rate constants were evaluated using the integrated rate equations.

\section{Results and discussion}

In the present work, electron transfer reaction of vanadium substituted Keggin-type heteropolyanions (HPA) $\left[\mathrm{PV}^{\mathrm{V}} \mathrm{W}_{11} \mathrm{O}_{40}\right]^{4-}\left(\mathrm{PV}_{1}\right)$ and $\left[\mathrm{PV}_{2}{ }_{2} \mathrm{~W}_{10} \mathrm{O}_{40}\right]^{5-}$ $\left(\mathrm{PV}_{2}\right)$ with $\mathrm{NADH}$ has been examined under non enzymic condition.

\subsection{Stoichiometry of the reaction}

$\mathrm{CV}$ of $0.5 \mathrm{mM}$ of $\mathrm{NADH}$ in phosphate buffer of $\mathrm{pH}$ 6 shows an irreversible anodic peak potential at $0.805 \mathrm{~V}$ for the electrochemical oxidation of NADH to $\mathrm{NAD}^{+}$(figure 1a). The $\mathrm{CV}$ of $\mathrm{PV}_{1}$ in phosphate buffer (figure $1 \mathrm{~b}$ ) shows a cathodic peak at $0.626 \mathrm{~V}$ and that of $\mathrm{PV}_{2}$ (figure 1c) shows a cathodic peak at $0.473 \mathrm{~V}$. When HPA is added to the aqueous buffered medium $(\mathrm{pH}=6)$ containing $\mathrm{NADH}$, the height of the anodic peak of NADH gradually decreases. For the reaction mixture containing $\left(\mathrm{NADH}+\mathrm{PV}_{1}\right) /\left(\mathrm{NADH}+\mathrm{PV}_{2}\right)$ in the ratio $1: 2$ the anodic peak corresponding to the oxidation of $\mathrm{NADH}$ and cathodic peak of $\mathrm{PV}_{1} / \mathrm{PV}_{2}$ completely disappeared (figures $1 \mathrm{~d}$ and e). This shows that two moles of HPA are needed for the oxidation of one mole of NADH.

UV-Visible spectrum of NADH shows a characteristic peak at $340 \mathrm{~nm}\left(\varepsilon=6300 \mathrm{~mol}^{-1} \mathrm{~cm}^{-1}\right)$ which was employed to monitor the [NADH]. To an aqueous buffered medium $(\mathrm{pH}=6)$ containing $\mathrm{NADH}$ $(0.1 \mathrm{mM})$ on adding $\mathrm{PV}_{1} / \mathrm{PV}_{2}$, the optical density (OD) at $340 \mathrm{~nm}$ decreases (figures 2 and 3). By measuring the decrease in OD at $340 \mathrm{~nm}$, the amount of [NADH] consumed and [NADH]/[HPA] was calculated. The optical measurement studies also show that two moles of HPA are needed for the oxidation of one mole of NADH. 


\subsection{Products of the reaction}

Reaction mixtures containing $\left(\mathrm{NADH}+\mathrm{PV}_{1}\right)$ and $\left(\mathrm{NADH}+\mathrm{PV}_{2}\right)$ in the ratio $1: 2$ were prepared and kept aside for few hours for the completion of the reaction and then UV-Visible spectrum was recorded (figure 4). The optical spectral features are comparable to those of the respective one electron reduced heteropoly blue (HPB) of the HPA, i.e. $\left[\mathrm{PV}^{\mathrm{IV}}\right.$ $\left.\mathrm{W}_{11} \mathrm{O}_{40}\right]^{5-}$ and $\left[\mathrm{PV}^{\mathrm{IV}} \mathrm{V}^{\mathrm{V}} \mathrm{W}_{11} \mathrm{O}_{40}\right]^{6-}$. The characteristic peaks were assigned as per previous investigations ${ }^{24,25}$ where the HPBs were produced by controlled potential electrolysis (table 1). One electron reduced heteropoly blue of the corresponding HPA is the one of the products of NADH oxidation.

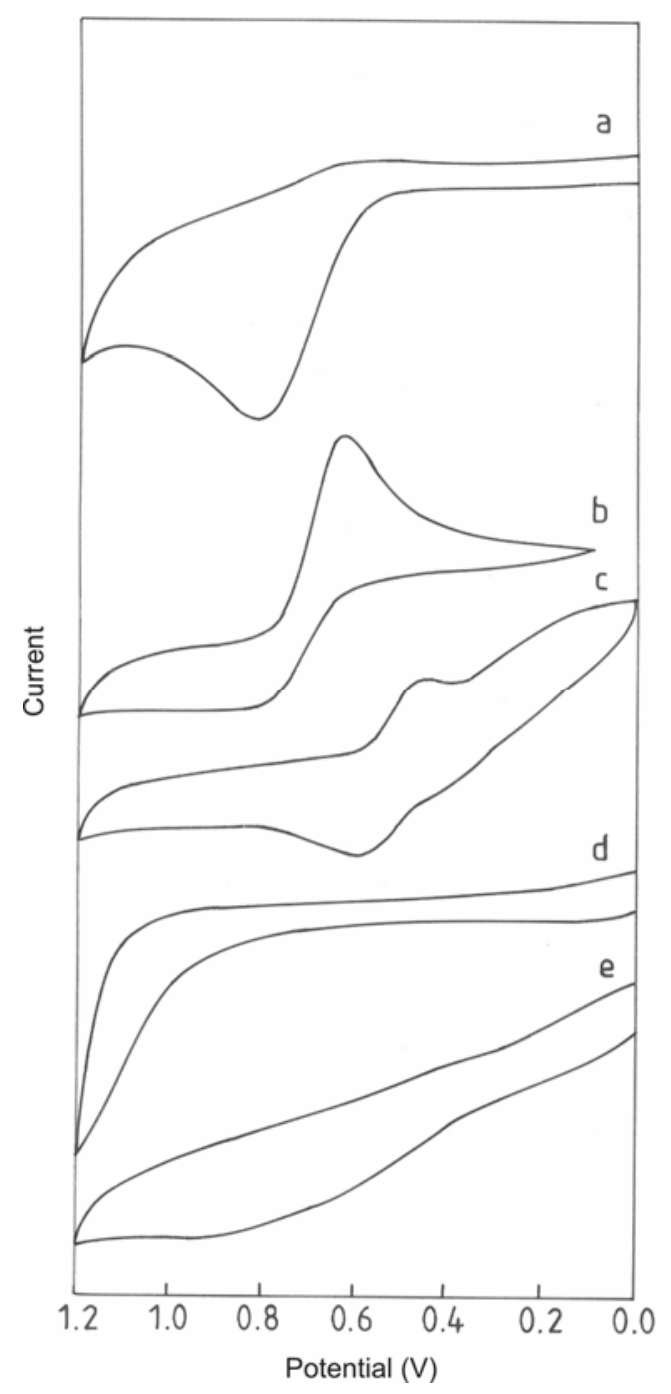

Figure 1. Cyclic voltammaograms of (a) $0.1 \mathrm{mM}$ NADH; (b) $0.2 \mathrm{mM} \mathrm{PV}$; (c) $0.2 \mathrm{mM} \mathrm{PV}$; (d) $0.1 \mathrm{M}$ $\mathrm{NADH}+0.2 \mathrm{mM} \mathrm{PV}{ }_{1}$; (e) $0.1 \mathrm{M} \mathrm{NADH}+0.2 \mathrm{mM} \mathrm{PV}_{2}$ (in phosphate buffer of $\mathrm{pH}$ 6; scan rate: $100 \mathrm{mV} \mathrm{s}^{-1}$ ).
Figure $5 \mathrm{a}$ is the EPR spectrum of reaction mixture containing $\mathrm{NADH}$ and $\mathrm{PV}_{1}$ in the ratio $1: 2$ in phosphate buffer of $\mathrm{pH} 6$ after completion of the reaction at room temperature. It shows a typical 8 line pattern expected for vanadium (IV) with $d^{1}$ configuration $\left({ }^{51} \mathrm{~V}, \mathrm{I}=7 / 2,100 \%\right)$. In $\mathrm{PV}_{1}$, vanadium is in +5 oxidation state and EPR silent. The 8 line EPR spectrum ascertains that during the electron transfer reaction, $\mathrm{PV}_{1}$ has accepted one electron from NADH to form the HPB, viz. $\left[\mathrm{PV}^{\mathrm{IV}} \mathrm{W}_{11} \mathrm{O}_{40}\right]^{5-}$ and the electron transfer reaction can be represented as follows.

$$
\begin{aligned}
& 2\left[\mathrm{PV}^{\mathrm{V}} \mathrm{W}_{11} \mathrm{O}_{40}\right]^{4-}+\mathrm{NADH} \rightleftharpoons \\
& 2\left[\mathrm{PV}^{\mathrm{IV}} \mathrm{W}_{11} \mathrm{O}_{40}\right]^{5-}+\mathrm{NAD}^{+}+\mathrm{H}^{+} .
\end{aligned}
$$

A complication inherent in the study of multi-electron transfer processes by polyoxovanadium containing anions is the capacity of these anions to be reduced by one or more electrons, i.e. in the two electron

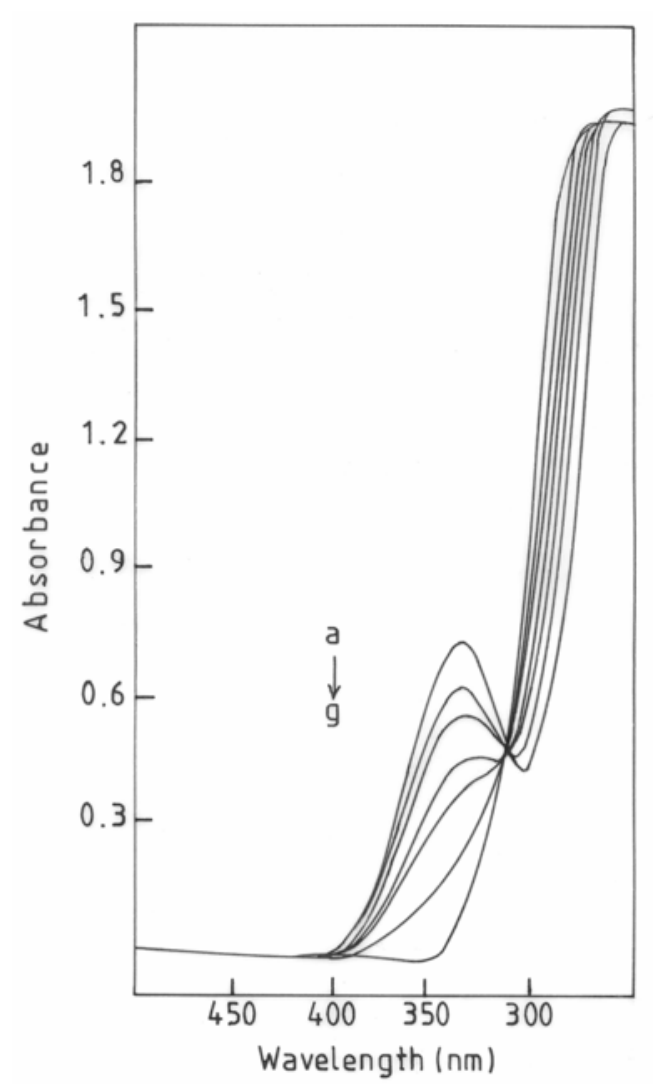

Figure 2. UV-Visible spectra of (a) $0.1 \mathrm{mM} \mathrm{NADH}$; (b) $0.1 \mathrm{mM} \mathrm{NADH}+0.03 \mathrm{mM} \mathrm{PV}_{1}$; (c) $0.1 \mathrm{mM} \mathrm{NADH}+$ $0.05 \mathrm{mM} \mathrm{PV}$; (d) $0.1 \mathrm{mM} \mathrm{NADH}+0.08 \mathrm{mM} \mathrm{PV}_{1}$; (e) $0.1 \mathrm{mM} \mathrm{NADH}+0.1 \mathrm{mM} \mathrm{PV}_{1}$; (f) $0.1 \mathrm{mM} \mathrm{NADH} \mathrm{+}$ $0.15 \mathrm{mM} \mathrm{PV}_{1}$; (g) $0.1 \mathrm{mM} \mathrm{NADH}+0.2 \mathrm{mM} \mathrm{PV}_{1}$ (in phosphate buffer of $\mathrm{pH} 6$; after completion of reaction). 
oxidation of NADH (1), $\mathrm{PV}_{2}$ can accept either two electrons or one electron (3 and 4).

$\left[\mathrm{PV}_{2}{ }^{\mathrm{V}} \mathrm{W}_{10} \mathrm{O}_{40}\right]^{5-}+2 \mathrm{e} \rightleftharpoons\left[\mathrm{PV}^{\mathrm{IV}} \mathrm{V}^{\mathrm{IV}} \mathrm{W}_{10} \mathrm{O}_{40}\right]^{7-}$

$\left[\mathrm{PV}_{2}{ }^{\mathrm{V}} \mathrm{W}_{10} \mathrm{O}_{40}\right]^{5-}+\mathrm{e} \rightleftharpoons\left[\mathrm{PV}^{\mathrm{IV}} \mathrm{V}^{\mathrm{V}} \mathrm{W}_{10} \mathrm{O}_{40}\right]^{6-}$

If one mole of HPA accepts two electrons (3), both vanadium (V) will be reduced to vanadium (IV) to give two electron reduced HPB $\left[\mathrm{PV}^{\mathrm{IV}} \mathrm{V}^{\mathrm{IV}} \mathrm{W}_{10} \mathrm{O}_{40}\right]^{7-}$. In such case EPR spectrum will give 8 line pattern. If one mole of HPA accepts one electron (4), it will give one electron reduced $\mathrm{HPB},\left[\mathrm{PV}^{\mathrm{IV}} \mathrm{V}^{\mathrm{V}} \mathrm{W}_{10} \mathrm{O}_{40}\right]^{6-}$ i.e. only one of the vanadium $(\mathrm{V})$ will be reduced to vanadium (IV). In order to ascertain the reduction product, EPR spectrum of the reaction mixture containing $\mathrm{NADH}$ and $\mathrm{PV}_{2}$ in the ratio $1: 2$ in buffered medium $(\mathrm{pH}=6)$ was prepared. After the

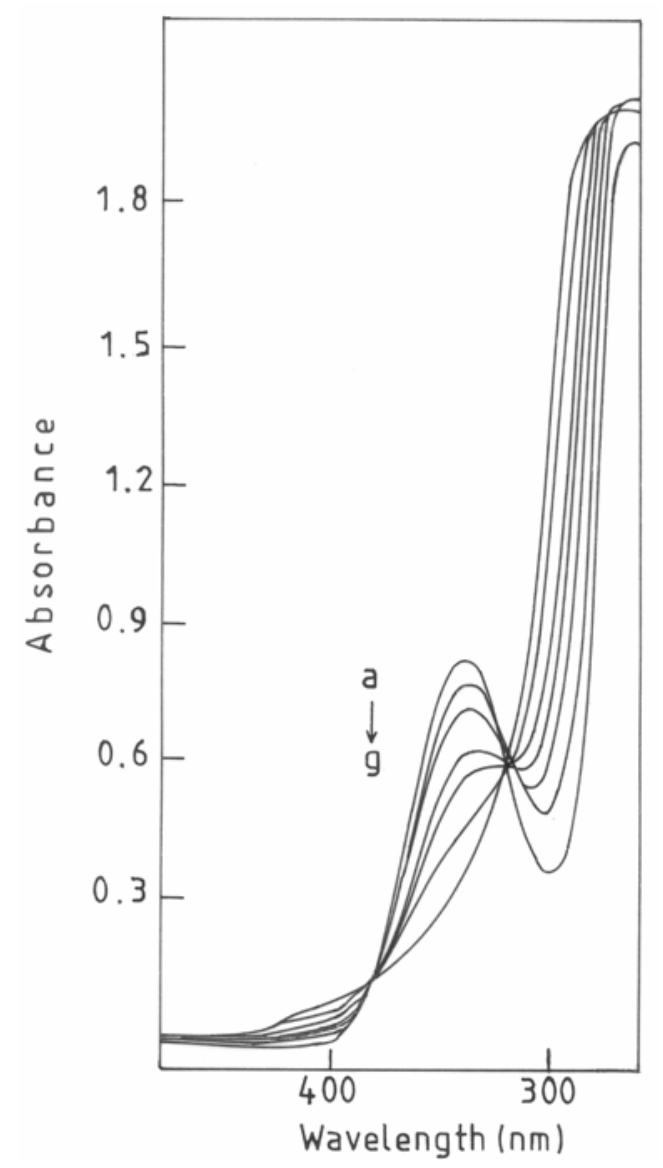

Figure 3. UV-Visible spectra of (a) $0.1 \mathrm{mM} \mathrm{NADH;} \mathrm{(b)}$ $0.1 \mathrm{mM} \mathrm{NADH}+0.03 \mathrm{mM} \mathrm{PV}_{2}$; (c) $0.1 \mathrm{mM} \mathrm{NADH}+$ $0.05 \mathrm{mM} \mathrm{PV}_{2}$; (d) $0.1 \mathrm{mM} \mathrm{NADH}+0.08 \mathrm{mM} \mathrm{PV}_{2}$; (e) $0.1 \mathrm{mM} \mathrm{NADH}+0.1 \mathrm{mM} \mathrm{PV}$; (f) $0.1 \mathrm{mM} \mathrm{NADH}+$

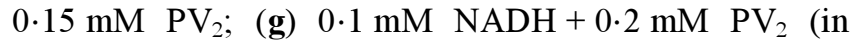
phosphate buffer of $\mathrm{pH} 6$; after completion of reaction). completion of reaction, EPR spectrum was recorded at room temperature. The spectrum (figure $5 \mathrm{~b}$ ) shows 15 line pattern.

$\mathrm{PV}_{2}$ is a 1,2-isomer with the two $\mathrm{VO}_{6}$ octahedra sharing their corners (VOV bond angle is $150^{\circ}$ ). The two vanadium nuclei are in +5 oxidation state under same environment. During NADH oxidation, one electron reduced HPB is formed. The resulting one electron reduced HPB $\left[\mathrm{PV}^{\mathrm{IV}} \mathrm{V}^{\mathrm{V}} \mathrm{W}_{10} \mathrm{O}_{40}\right]^{6-}$ is a mixedvalence $\mathrm{V}^{\mathrm{IV}} / \mathrm{V}^{\mathrm{V}}$ species. At room temperature the unpaired electron will be interacting equally with the two adjacent vanadium nuclei $\left({ }^{51} \mathrm{~V}, I=7 / 2,100 \%\right)$ by a thermally activated hopping process ${ }^{26}$ and this leads to 15 line pattern in the EPR spectrum at room temperature. The EPR spectrum of the reduction product obtained in the present study is similar to the EPR spectrum of one electron reduced HPB prepared by controlled potential electrolysis ${ }^{26-28}$ of $\left[\mathrm{PV}_{2}\right.$ $\left.\mathrm{W}_{10} \mathrm{O}_{40}\right]^{5-}$. The EPR parameters are summarized in table 2. The stoichiometric equation for the reduction of $\mathrm{PV}_{2}$ by NADH may be represented as follows:

$$
\begin{aligned}
& 2\left[\mathrm{PV}^{\mathrm{V}} \mathrm{V}^{\mathrm{V}} \mathrm{W}_{10} \mathrm{O}_{40}\right]^{5-}+\mathrm{NADH} \rightleftharpoons \\
& 2\left[\mathrm{PV}^{\mathrm{IV}} \mathrm{V}^{\mathrm{V}} \mathrm{W}_{10} \mathrm{O}_{40}\right]^{6-}+\mathrm{NAD}^{+}+\mathrm{H}^{+} .
\end{aligned}
$$

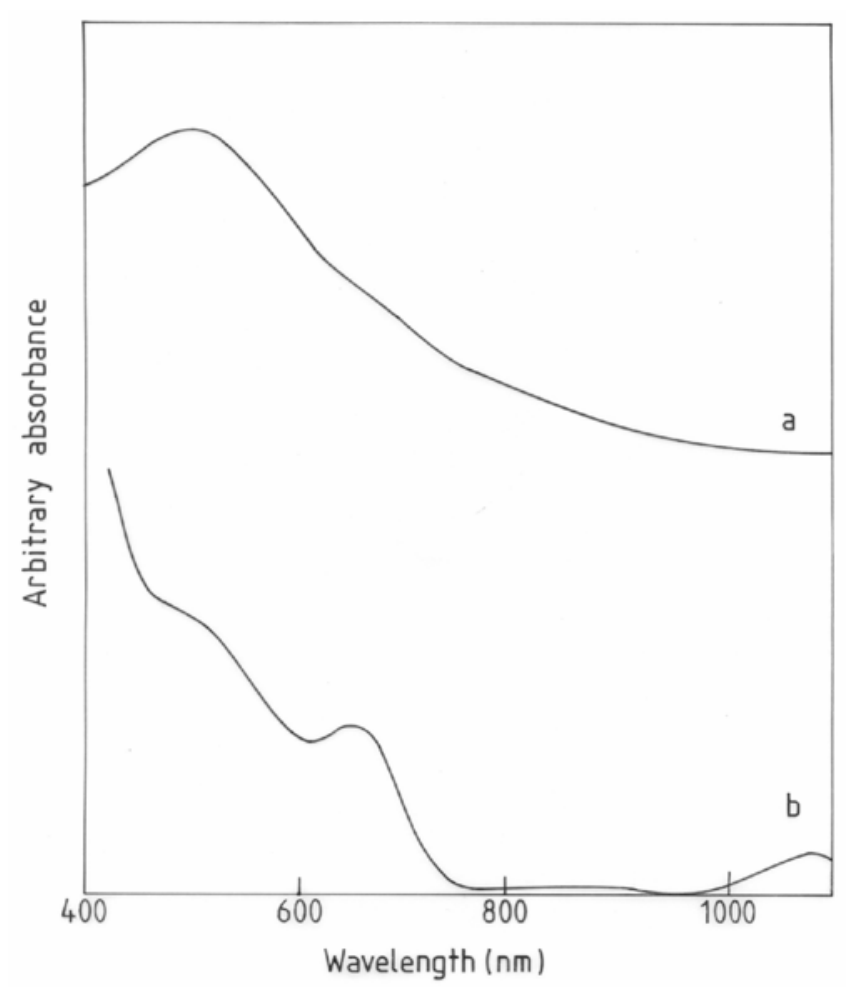

Figure 4. UV-Visible spectra of one electron reduced heteropoly blue (a) $\left[\mathrm{PV}^{\mathrm{IV}} \mathrm{W}_{11} \mathrm{O}_{40}\right]^{5-}$; (b) $\left[\mathrm{PV}^{\mathrm{IV}} \mathrm{V}^{\mathrm{V}} \mathrm{W}_{10} \mathrm{O}_{40}\right]^{6-}$ (obtained by $\mathrm{NADH}$ reduction of $\mathrm{PV}_{1} / \mathrm{PV}_{2}$ ). 
Table 1. Optical spectral data characteristics of heteropoly blues.

\begin{tabular}{llcll}
\hline $\begin{array}{l}\text { Mode of } \\
\text { reduction }\end{array}$ & $\begin{array}{c}\left.\mathrm{PV}^{\mathrm{IV}} \mathrm{W}_{11} \mathrm{O}_{40}\right]^{5-} \\
\lambda(\mathrm{nm})\end{array}$ & $\begin{array}{c}\left.\mathrm{PV}^{\mathrm{IV}} \mathrm{V}^{\mathrm{V}} \mathrm{W}_{10} \mathrm{O}_{40}\right]^{6-} \\
\lambda(\mathrm{nm})\end{array}$ & \multicolumn{1}{c}{ Assignment } & Reference \\
\hline By NADH & - & $1060(S h)$ & $\mathrm{V}^{\mathrm{IV}} \rightarrow \mathrm{V}^{\mathrm{V}}(\mathrm{IVCT})$ & This work \\
& $845(S h-b)$ & - & $d-d$ & \\
& $685(S h)$ & 651 & $d-d$ & \\
& 503 & $500(S h)$ & $\mathrm{V}^{\mathrm{IV}} \rightarrow \mathrm{W}^{\mathrm{VI}}(\mathrm{IVCT})$ & \\
Electrochemical & - & $1130(S h)$ & $\mathrm{V}^{\mathrm{IV}} \rightarrow \mathrm{V}^{\mathrm{V}}(\mathrm{IVCT})$ & 24,25 \\
& $835(S h-b)$ & $830(S h-b)$ & $d-d$ & \\
& $690(S h)$ & $645(S h)$ & $d-d$ & \\
& 500 & $526(S h)$ & $\mathrm{V}^{\mathrm{IV}} \rightarrow \mathrm{W}^{\mathrm{VI}}(\mathrm{IVCT})$ & \\
& & &
\end{tabular}

Sh: Shoulder; Sh-b: Shoulder broad; IVCT: Intervalence charge transfer

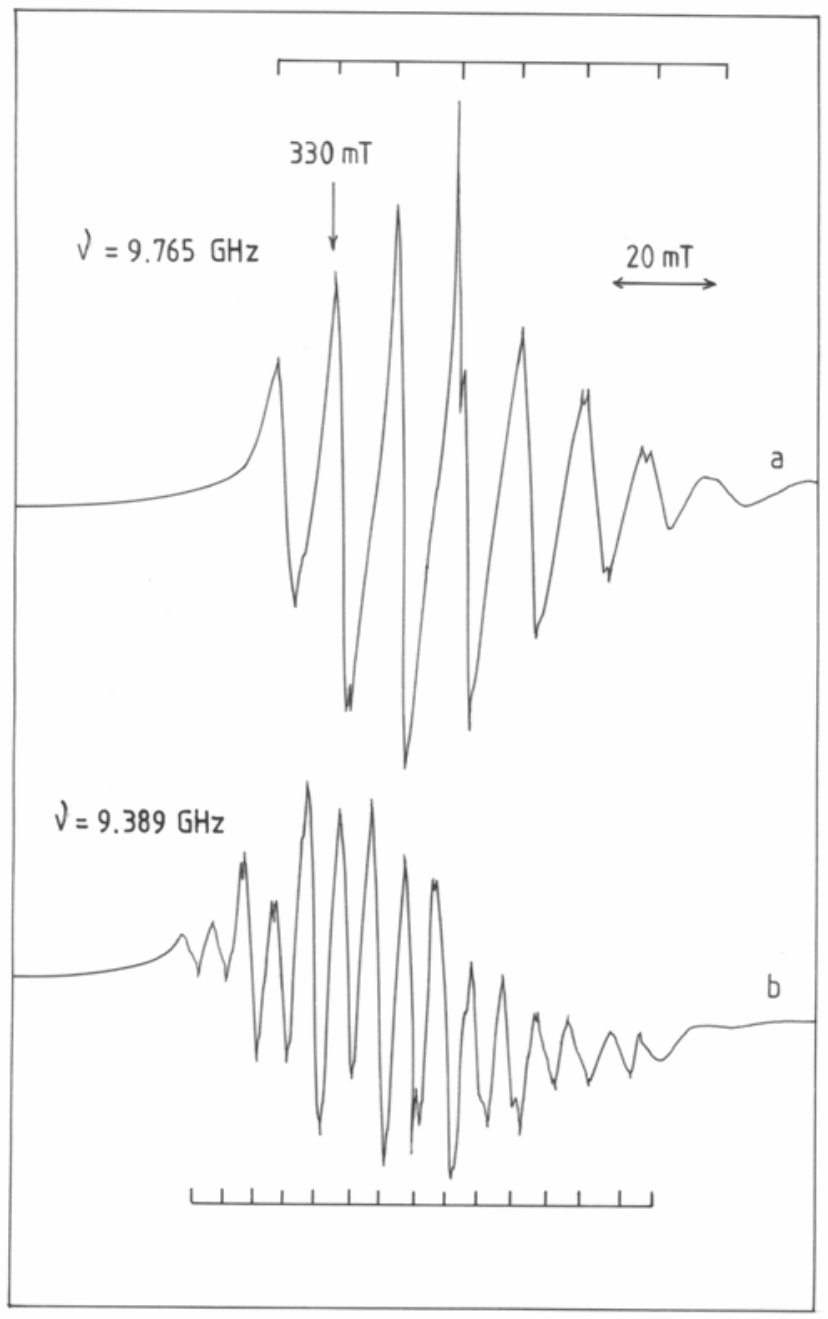

Figure 5. X-band ESR spectra of one electron reduced heteropoly blue (a) $\left[\mathrm{PV}^{\mathrm{IV}} \mathrm{W}_{11} \mathrm{O}_{40}\right]^{5-}$; (b) $\left[\mathrm{PV}^{\mathrm{V}} \mathrm{V}^{\mathrm{V}} \mathrm{W}_{10} \mathrm{O}_{40}\right]^{6-}$ (obtained by $\mathrm{NADH}$ reduction of $\mathrm{PV}_{1} / \mathrm{PV}_{2}$ ) recorded at room temperature.

Optical, electrochemical and EPR studies show that

(i) 1 mole of NADH reduces two moles of HPA.

(ii) $\mathrm{PV}_{1}$ and $\mathrm{PV}_{2}$ act as one electron acceptor. (iii) The products are $\mathrm{NAD}^{+}$and one electron reduced HPB of the corresponding HPA.

\subsection{Rate-law}

The rate of the electron transfer reaction between $\mathrm{NADH}$ and $\mathrm{PV}_{1}$ is very fast and we were unable to follow the kinetics by conventional technique. The rate of the electron transfer reaction between NADH and $\mathrm{PV}_{2}$ was measured spectrophotometrically by monitoring the decrease in [NADH] at $340 \mathrm{~nm}$ under second order conditions. The reaction rates were measured with equal and unequal concentration the reactants in phosphate buffer of $\mathrm{pH} 6$ at $303 \mathrm{~K}$. The results are summarized in table 3 . The reaction follows simple second order kinetics, i.e. order with respect to $[\mathrm{NADH}]$ is one and order with respect to $\left[\mathrm{PV}_{2}\right]$ is also one. The rate law for the electron transfer reaction is

$$
-\frac{\mathrm{d}[\mathrm{NADH}]}{\mathrm{d} t}=k_{2}[\mathrm{NADH}][\mathrm{HPA}] \text {. }
$$

\subsection{Mechanism}

The rate of oxidation of NADH by enzymes present in several biological membranes, viz. cat ventricles, human heart erythrocytes, mouse liver plasma membranes and rat liver microsomes was stimulated by vanadates, ${ }^{6-8}$ Vanadates are capable of oxidizing $\mathrm{NADH}$ under non-enzymic conditions. Isopolydecavanadate in presence of phosphate buffer was found to be an effective oxidant of NADH compared to other forms of vanadates viz. orthovanadate and metavanadate. ${ }^{9,10}$ Based on the experimental results, a mechanism involving superoxide intermediate for the oxidation of NADH by decavanadate was proposed by Vijaya and Ramasarma ${ }^{10}$ (scheme 2). 
Table 2. ESR spectral data characteristics of heteropoly blues.

\begin{tabular}{lcccccl}
\hline & \multicolumn{2}{c}{$\left[\mathrm{PV}^{\mathrm{IV}} \mathrm{W}_{11} \mathrm{O}_{40}\right]^{5-}$} & & \multicolumn{2}{c}{$\left.\mathrm{PV}^{\mathrm{IV}} \mathrm{V}^{\mathrm{V}} \mathrm{W}_{10} \mathrm{O}_{40}\right]^{6-}$} & \\
\cline { 2 - 3 } Mode of reduction & $g_{\text {iso }}$ & $A_{\text {iso }}\left(10^{-4} \mathrm{~cm}^{-1}\right)$ & & $g_{\text {iso }}$ & $A_{\text {iso }}\left(10^{-4} \mathrm{~cm}^{-1}\right)$ & Reference \\
\hline By NADH & 1.963 & 91.1 & & 1.969 & 47.6 & This work \\
Electrochemical & 1.952 & 90.7 & & 1.963 & 51.5 & $26-28$ \\
\hline
\end{tabular}

Table 3. Bimolecular rate constant for the oxidation of NADH by $\mathrm{PV}_{2}$ in phosphate buffer of $\mathrm{pH} 6$ at $303 \mathrm{~K}$.

\begin{tabular}{lcc}
\hline $\mathrm{NADH}(\mathrm{mM})$ & $\mathrm{PV}_{2}(\mathrm{mM})$ & $k_{2}\left(\mathrm{M}^{-1} \mathrm{~s}^{-1}\right)$ \\
\hline $0 \cdot 10$ & $0 \cdot 20$ & $25 \cdot 3$ \\
$0 \cdot 12$ & $0 \cdot 20$ & $22 \cdot 4$ \\
$0 \cdot 15$ & $0 \cdot 20$ & $21 \cdot 7$ \\
$0 \cdot 20$ & $0 \cdot 15$ & 21.6 \\
$0 \cdot 20$ & $0 \cdot 20$ & $24 \cdot 6$ \\
\hline
\end{tabular}

Average $k_{2}=23 \cdot 1 \pm 1 \cdot 4 \mathrm{M}^{-1} \mathrm{~s}^{-1}$

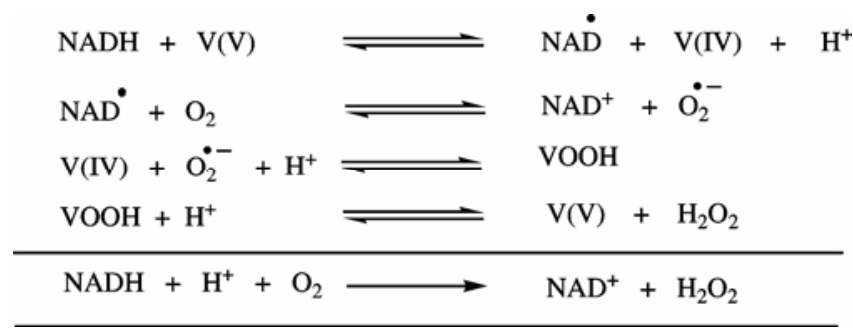

Scheme 2.

The oxidants employed in the present studies are also polymeric anions containing vanadium $(\mathrm{V})$. The reduced form of the above polyanions, namely heteropolyblues can react with molecular oxygen to produce superoxide radicals. ${ }^{29,30}$ Therefore, there is a possibility that NADH oxidation by $\mathrm{PV}_{1} / \mathrm{PV}_{2}$ may proceed through superoxide radical intermediate as shown in scheme 3 .

If the reaction proceeds with the formation of superoxide radical intermediate, there will be uptake of molecular oxygen, i.e. one mole of oxygen will be consumed for the oxidation of one mole of NADH (scheme 3). In order to ascertain whether there is uptake of molecular oxygen or not, oxygraph measurements were performed. The results clearly show that there is no uptake of molecular oxygen during the course of the oxidation of NADH by $\mathrm{PV}_{1} / \mathrm{PV}_{2}$. Further for scheme 3, to be operative, HPB will be only an intermediate. But we have found that the end product of NADH oxidation by $\mathrm{PV}_{1} / \mathrm{PV}_{2}$ is HPB (Optical and ESR data). This excludes the possibility of reaction proceeding through superoxide intermediate in the present study. Based

$$
\begin{array}{ll}
\mathrm{NADH}+\left[\mathrm{PV}^{\mathrm{V}} \mathrm{W}_{11} \mathrm{O}_{40}\right]^{4-} & \mathrm{NADH}^{+}+\left[\mathrm{PV}^{\mathrm{IV}} \mathrm{W}_{11} \mathrm{O}_{40}\right]^{5-} \\
\mathrm{NADH}^{+}+\left[\mathrm{PV}^{\mathrm{V}} \mathrm{W}_{11} \mathrm{O}_{40}\right]^{4} & \mathrm{NAD}^{+}+\left[\mathrm{PV}^{\mathrm{IV}} \mathrm{W}_{11} \mathrm{O}_{40}\right]^{5-}+\mathrm{H}^{+} \\
2\left[\mathrm{PV}^{\mathrm{IV}} \mathrm{W}_{11} \mathrm{O}_{40}\right]^{5-}+2 \mathrm{O}_{2} & \dot{\mathrm{O}}_{2}^{-}+2\left[\mathrm{PV}^{\mathrm{V}} \mathrm{W}_{11} \mathrm{O}_{40}\right]^{4-} \\
2 \mathrm{O}_{2}^{-}+2 \mathrm{H}^{+} & \mathrm{O}_{2}+\mathrm{H}_{2} \mathrm{O}_{2} \\
\hline \mathrm{NADH}+\mathrm{H}^{+}+\mathrm{O}_{2} \longrightarrow \mathrm{NAD}^{+}+\mathrm{H}_{2} \mathrm{O}_{2}
\end{array}
$$

Scheme 3.

$$
\begin{aligned}
\mathrm{NADH}+\left[\mathrm{PV}^{\mathrm{V}} \mathrm{W}_{11} \mathrm{O}_{40}\right]^{4-} & \frac{\mathrm{k}_{1}}{\mathrm{k}_{-1}} \mathrm{NAD \dot {H } ^ { + }}+\left[\mathrm{PV}^{\mathrm{IV}} \mathrm{W}_{10} \mathrm{O}_{40}\right]^{5-} \\
\mathrm{NADH}^{+}+\mathrm{B} & \frac{\mathrm{k}_{2}}{\mathrm{k}_{-2}} \mathrm{NAD}+\mathrm{BH}^{+} \\
\mathrm{NAD}+\left[\mathrm{PV}^{\mathrm{V}} \mathrm{W}_{11} \mathrm{O}_{40}\right]^{4-} & \frac{\mathrm{k}_{3}}{\mathrm{k}_{-3}} \mathrm{NAD}^{+}+\left[\mathrm{PV}^{\mathrm{IV}} \mathrm{W}_{11} \mathrm{O}_{40}\right]^{5-}
\end{aligned}
$$

Scheme 4.

$$
\begin{aligned}
& \mathrm{NADH}+\left[\mathrm{PV}^{\mathrm{V}} \mathrm{V}^{\mathrm{V}} \mathrm{W}_{10} \mathrm{O}_{40}\right]^{5-} \frac{\mathrm{k}_{1}}{\mathrm{k}_{1}} \mathrm{NAD \dot {H } ^ { + }}+\left[\mathrm{PV}^{\mathrm{V}} \mathrm{V}^{\mathrm{IV}} \mathrm{W}_{10} \mathrm{O}_{40}\right]^{6-} \\
& \mathrm{NADH}^{+}+\mathrm{B} \frac{\mathrm{k}_{2}}{\mathrm{k}_{-2}} \mathrm{NAD}+\mathrm{BH}^{+} \\
& \mathrm{NAD}+\left[\mathrm{PV}^{\mathrm{V}} \mathrm{V}^{\mathrm{V}} \mathrm{W}_{10} \mathrm{O}_{40}\right]^{5-} \frac{\mathrm{k}_{3}}{\mathrm{k}_{-3}} \mathrm{NAD}^{+}+\left[\mathrm{PV}^{\mathrm{V}} \mathrm{V}^{\mathrm{IV}} \mathrm{W}_{10} \mathrm{O}_{40}\right]^{6-}
\end{aligned}
$$

Scheme 5.

on the results of present studies, the following mechanism can be envisaged for the electron transfer reaction of $\mathrm{NADH}$ with $\mathrm{PV}_{1}$ and $\mathrm{PV}_{2}$ (schemes 4 and 5).

The above mechanism involves multiple electronproton-electron transfer steps. Initially an electron is transferred from NADH to HPA to give $\mathrm{NADH}^{\circ+}$. The solvent water molecule (B) abstracts the proton from $\mathrm{NADH}^{++}$to give $\mathrm{NAD}^{\circ}$ which subsequently reacts with another molecule of HPA to give $\mathrm{NAD}^{+}$. For such a mechanism either electron transfer from NADH to HPA or proton transfer from $\mathrm{NADH}^{\circ+}$ to $\mathrm{B}$ may be rate-limiting step. For electron-transfer step to be rate-limiting the following condition should be satisfied.

$$
k_{-1}[\mathrm{HPB}]<k_{2}[\mathrm{~B}] .
$$

Assuming equal radii for the reactants, the diffusion controlled rate constant $k_{-1}$ can be calculated by the modified Debye equation ${ }^{11}$ 


$$
k_{-1}=\frac{8 R T}{3 \eta}
$$

At $303 \mathrm{~K}$, with $\eta=0.01 \mathrm{P}, k_{-1}=6.6 \times 10^{9} \mathrm{dm}^{3}$ $\mathrm{mol}^{-1} \mathrm{~s}^{-1}$. If we assume $[\mathrm{HPB}]=0.2 \times 10^{-3} \mathrm{M}$ (maximum concentration of HPB formed during oxidation of NADH by HPA), then $k_{-1}$ [HPB] $=$ $1.3 \times 10^{6} \mathrm{~s}^{-1}$. A laser flash photolysis ${ }^{31}$ shows that $k_{2}$ $[\mathrm{B}]=12 \times 10^{6} \mathrm{~s}^{-1}$. The inequality $k_{-1}[\mathrm{HPB}]<k_{2}[\mathrm{~B}]$ exists even at the end of the reaction. Therefore, the initial electron transfer step appears to be the ratelimiting step in the oxidation of NADH by vanadium substituted Keggin-type heteropolyanions. This mechanism (schemes 4 and 5) is in accordance with the mechanism proposed for the oxidation of NADH by vanadium substituted Dawson-type heteropolyanions $^{32-34}$ and oxidation of NADH by ferrocenium ions. $^{3}$

\section{Conclusion}

Reduction of $\mathrm{PV}_{1} / \mathrm{PV}_{2}$ by NADH proceeds smoothly in phosphate buffer of $\mathrm{pH} 6$ at ambient temperature. For the reduction of 2 moles of HPA 1 mole of $\mathrm{NADH}$ is consumed. The products are $\mathrm{NAD}^{+}$and one electron reduced heteropoly blues. There is no uptake of molecular oxygen during the reaction. The reaction is second order. Order with respect to [NADH] is one and order with respect to [HPA] also one. The reaction proceeds through multiple electron-proton-electron transfer steps in which the initial one electron transfer is the rate-limiting step.

\section{Acknowledgements}

The authors thank National Institute of Health, Bethesda, USA for EPR and Clark electrode facilities. The authors thank the Managing Board of V.H.N. Senthikumara Nadar College, Virudhunagar for providing research facilities. The authors also thank University Grants Commission (UGC), New Delhi for the award of major research project.

\section{References}

1. Pollak N, Dolle C and Zeigler M 2007 Biochem. J. 402205

2. Belenky P, Bogan K L and Brenner C 2007 Trends Biochem. Sci. 3212

3. Carlson B W and Miller L L $1983 \mathrm{~J}$. Am. Chem. Soc. 1057453
4. Rao A V S and Ramasarma T 2000 Biochem. Biophys. Acta 1474321

5. Shi X and Dalal N S 1993 Arch. Biochem. Biophys. 307336

6. Patole M S and Ramasarma T 1988 Free Rad. Res. Comms. 4201

7. Patole M S, Gullapalli S and Ramasarma T $1988 \mathrm{~J}$. Neurochem. 51491

8. Khandke L, Gullapalli S, Patole M S and Ramasarma T 1986 Arch. Biochem. and Biophys. 244742

9. Ramasarma T, Mac Keller W and Crane F L 1980 Indian J. Biochem. Biophys. 171638

10. Vijaya S and Ramasarma T 1984 J. Inorg. Biochem. 20247

11. Carlson B W, Miller L L, Neta P and Grodkowski J 1984 J. Am. Chem. Soc. 1067233

12. Carlson B W and Miller L L $1985 \mathrm{~J}$. Am. Chem. Soc. 107479

13. Nechay B R 1984 Ann. Rev. Pharmacol. Toxycol. 24 501

14. Chasteen N D 1983 Structure and Bonding 53107

15. Erdmann E, Werdan K, Krawietz W, Schmitz W and Scholz H 1984 Biochem. Pharmac. 33945

16. Evangelou A M 2002 Crit. Rev. Oncol/Hemat. 42249

17. Pope M T 1983 Heteropoly and isopoly oxometalates (New York: Springer-Verlag)

18. Weinstok I A 1998 Chem. Rev. 98113

19. Newman R and Lissel M 1989 J. Org. Chem. 544607

20. Newman R and Lissel M 1989 J. Am. Chem. Soc. 114 7278

21. Katsoulis D E 1998 Chem. Rev. 98359

22. Domaille P J 1984 J. Am. Chem. Soc. 1067677

23. Lange N A 1969 Hand book of chemistry (New York: Mc-Graw-Hill), 10th edn, p 972

24. Altenau J J, Pope M T, Prados R A and So H 1975 Inorg. Chem. 14417

25. Smith D P and Pope M T 1973 Inorg. Chem. 12331

26. So $\mathrm{H}$ and Pope M T 1992 In Electron and proton transfer in chemistry and biology (eds) A Muller, $\mathrm{H}$ Ratajezak, W Junge and E Diemann Studies in physical and theoretical chemistry (Amsterdam: Elsevier Science Publishers), vol. 78, p. 71

27. Smith D P, So H, Bender J and Pope M T 1973 Inorg. Chem. 12685

28. Varghese G M, Shunmugasundaram A, Murugesan R and Jeyabalan T 2002 Proc. Indian Acad. Sci. (Chem. Sci.) $\mathbf{1 1 4} 75$

29. Kuznetsova L I, Maksimovskaya R I, Subocheva O A and Matveev K I 1986 Kinet. Katal. 27806

30. Kuznetsova L I, Maksimovskaya R I and Matveev K I 1983 Izv. Akad. Nauk SSSR, Ser. Khim. 726

31. Martens F M, Verhoeven J W, Varma C A G O and Bergwerf P 1983 J. Photochem. 2299

32. Essaadi K, Keita B, Nadjo L and Contant R $1994 \mathrm{~J}$. Electroanal. Chem. $\mathbf{3 6 7} 275$

33. Keita B, Essaadi K, Nadjo L and Desmadril M 1995 Chem. Phys. Lett. 237411

34. Keita B, Essaadi K, Nadjo L, Contant R and Justum Y 1996 J. Electroanal. Chem. 404271 